Nippon Suisan Gakkaishi $\quad \mathbf{6 2}(2), 295-296$ (1996)

ミニシンポジウム 海洋生命科学における糖鎖生物学・糖鎖工学

魚類赤血球の中性 $\beta-N$-アセチルグルコサミニダーゼの性質とその応用*1

上 野 隆 二*2

三重大生物資源学部

及一Nアセチルグルコサミニダーゼ (NAG) は広く動

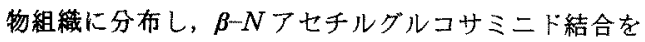
有する糟脂質，ムコ多糖，糖タンパク等の分解に関与す る硣素である。NAGの多様性について多くの報告があ るが，酸性 NAGであるへキソサニミダーゼA 抢よび B と中性 NAG であるへキりサニミダーゼCとはこれ らの欠損が先天性異常代謝病の一つである $\mathrm{GM}_{2}$ ガング リオシドースに関連することから，その相関性について 非常に注目されている。

著者は魚類血液中に上記 3 種の NAG が高い活性（1 つは中性 NAG, 残り 2 つは酸性 NAG）で存在するこ とを見出し（表 1)，1-3) 魚類血夜加 NAG isoenzymes $\sigma$ 生物学的機能や遗伝的相関性の研究のための醳素源とし て有用であることを指摘した。ここでは，中性 NAGを 中心に酵素の精製, 性質, 血液中での局在性, 魚種間で の分布等を述べると共に，中性 NAG 活性測定を利用し た凍結・解凍魚と非涷結魚との鑑別法への応用について むふれる。

\section{コイ赤血球中性 NAG}

コイ赤血球加ら中性 NAGの精製を行い，電気泳動的 に均質な酵素標品を得た。本䣼素の至適 $\mathrm{pH}$ は 6.5 であ った。DTT，2-MEによって強く活性化された。N-ア セチルグルコサミンや酶酸塩によって阻害されなかっ た。本醉素は $N$-アセチルグルコサミニド誘導体のみ特 異的に分解し，ヒト，ウシ，ラットの絪に存在するへキ ソサミニダーゼCに相当する酵素と推定した。また， 本醉素は狭い基筫特買性と緩和な反応条件加ら複合楉質 の構造研究の上で有用であった。っ-6)

\section{コイ白血球酸性 NAG}

コイ白血球加ら2 種の酸性 NAG（1 型およひ2 型) の精製を行い，電気泳動的に均質な酵素標品を得た。両 素は 5.0 に至適 $\mathrm{pH}, 0.2 \mathrm{mM}$ の Km, 116,000の分子 量をむち，N-アセチルガラクトサミン，N-アセチルグ ルコサミンおよひ酢酸塩によって阻害された。しかしな
がら，両酵素は熱安定性，電気泳動による移動度におい て美異が認められた。それらの結果から，1型および 2 型は，それぞれヒト組織のへキソサミニダーゼ $\mathrm{A}$ およ びBと推定された。さらに，1型はノイラニミダーゼ 处理によって 2 型から変換されることから2 型の前駆 体と推諭した。

\section{魚血液中の NAG の細胞内局在性および分布}

血液中には，少なくとも3つの異なった NAG が存在 した。すなわち，中性 NAG と 2 種の酸性 NAG であっ た。血液をパーコールによって，血獎，白血球，赤血球 画分に分け，各画分中のNAG 活性を测定した。中性 NAG は赤血球中に，酸性 NAGは白血球中にそれそれ 存在した。中性 NAG は潜在活性を示し，赤血球膜の破 壊によって初めて活性が発現したが，酸性 NAG は潜在 活性を示さず白血球膜と結合した酵菜と推定された。両 酵素は試験したすべての魚類にわたって分布していた が，中性 NAG はは乳類の血球中では見いたされなかっ た。ELISA 法により2種の酸性 NAG は免疫学的に同 一であったが，中性 NAGでは完全な同一性（酸性 NAGに対して $4060 \%$ response level) が喼められ なかった。

\section{赤血球中性 NAG 活性測定による 凍結・解凍魚と非凍結魚との鑑別法}

血球における中性 NAGの局在性および性質を利用し て，上記鑑別法の開発を試みた。その結果，鮮魚をたは 泠蔵魚の場合，凍結魚の血液に比へて非常に強い活性を 示した。本方法は市肘の淡水魚，海産魚に適用でき， 20 分以内で終了した。本方法をさらに簡単にするため， 鑑別試験紙による方法を開発した。すなわち，あらかじ め基質を染及込ませた濾阵に，血液を染及込ませ，室温 で 10 分間放置後, アルカリ液を一滴加え，UV下で蛍 光の有無を観察した。その結果，本方法は前者上りも簡 単に判別できた(表 2$) 。{ }^{7-10)}$

*1 Neutral $\beta-N$-acetylglucosaminidase from carp blood cells and its application.

*2 Ryuji Ueno (Faculty of Bioresources, Mie University, Tsu, Mie 514, Japan). 


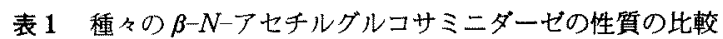

\begin{tabular}{|c|c|c|c|c|}
\hline Enzyme & Opt. pH & Heat stabiliy at $50^{\circ} \mathrm{C}$ & Inhibitor & Substrate specificity \\
\hline Hex $A^{* 1}$ & $4.5-5.0$ & Unstable & $\begin{array}{l}\text { Acetate } \\
\text { GlcNAc } \\
\text { GalNAc }\end{array}$ & $\begin{array}{c}\text { 4MU-GlcNAc }: 4 \mathrm{MU}-\mathrm{GalNAc} \\
8.6: 1\end{array}$ \\
\hline $\operatorname{Hex} B^{* 1}$ & $4.5-5.0$ & Stable & $\begin{array}{l}\text { Acetate } \\
\text { GlcNAc } \\
\text { GalNAc }\end{array}$ & $\begin{array}{c}\text { 4MU-GlcNAc : } 4 \mathrm{MU}-\text { GalNAc } \\
8.6: 1\end{array}$ \\
\hline $\operatorname{Hex} \mathrm{C}^{* 2}$ & $6.0-7.0$ & Unstable & GlcNAc & $4 \mathrm{MU}-\mathrm{GlcNAc}$ \\
\hline Carp Neutral NAG*3 & 6.5 & Unstable & GlcNAc & $\begin{array}{c}\text { 4MU-GlcNAc : } 4 \mathrm{MU} \text {-GalNAc } \\
76: 1\end{array}$ \\
\hline Acidic $\mathrm{NAG}^{* 3}$ & 4.5 & Stable & $\begin{array}{l}\text { Acetate } \\
\text { GlcNAc } \\
\text { GalNAc }\end{array}$ & $\begin{array}{c}\text { 4MU-GlcNAc : 4MU-GalNAc } \\
1.9: 1\end{array}$ \\
\hline
\end{tabular}

*1 Robinson et al. (1967).

*2 Braidman (1981).

*3 Partially purified.

表 2 試験紙を用いた生濓魚と凍結解凍魚との鑑 別結果

\begin{tabular}{|c|c|c|c|c|c|c|c|c|}
\hline \multirow{2}{*}{$\begin{array}{l}\text { Temperarure } \\
\left({ }^{\circ} \mathrm{C}\right)\end{array}$} & \multicolumn{8}{|c|}{ Storage periods (day) } \\
\hline & 1 & 2 & 3 & 4 & 5 & 6 & 7 & 8 \\
\hline & \multicolumn{8}{|c|}{ Carp } \\
\hline 4 & $\ldots * 1$ & - & - & - & - & $+^{* 2}$ & $H$ & $H$ \\
\hline-1 & - & - & - & - & - & - & - & - \\
\hline-20 & \# & m & $\mathrm{H}$ & H & H & m & 册 & H \\
\hline-40 & H & $H$ & \# & H & $\mathrm{H}$ & H & 世 & H \\
\hline
\end{tabular}

Red sea bream

\begin{tabular}{lllllllll}
4 & - & - & - & $H$ & $H$ & $H$ & $H$ & $H$ \\
-20 & $H$ & $H$ & $H$ & $H$ & $H$ & $H$ & $H$ & $H$ \\
\hline
\end{tabular}

*1 The minus sign means no fluorescence.

$* 2$ The plus sign means the degree of the fivorescence. ,$+>0.2-0.3 \mathrm{mU} / \mathrm{m} l$ of the neutral $\beta-N$-acetylglucosaminidase activity; $\mathrm{H},>1.1 \mathrm{mU} / \mathrm{m} l$.

\section{謝辞}

本研究を遂行するにあたり，共同研究者であった米国 カンサス大学医学部の袁 崇生博士, 中村学園女子短期 大学部の吉岡序子博士㧍よび九州大学名誉教授の故北御 閒学博士に索心から謝意を表す。

$$
\text { 文献 }
$$

1）上野隆二・菻下達雄・高橋 喬：コイ箊肉組織の $\beta-N-$ 一
セチルグルコサミニダーゼ. 三重大水研報，209-216 (1979).

2) R. Ueno and Y. Horiguchi: Distribution of $\beta-N$-acetylglucosaminidase in tissues of several fish spesies. Bull. Fac. Fish. Mie Univ., 11, 51-56 (1984).

3) R. Ueno, Y. Horiguchi, T. Morishita, and T. Takahashi: Partial purification of $\beta-N$-acetylglucosaminidase in carp red muscle and their general property. Bull. Fac. Fish. Mie Univ., 11, 43-50 (1984).

4) R. Ueno, C. Yuan, and Y. Horiguchi: Purification of $\beta-N^{-}$ acetylglucosaminidase from carp blood. Nippon Suisan Gakkaishi, 53, 1009-1016 (1987).

5) R. Ueno and C.-S. Yuan: Purification and properties of neutral $\beta$ - $N$-acetylglucosaminidase from carp blood. Biochim. Biophys. Acta, 1074, 79-84 (1991).

6) C.-S. Yuan, K. Yamaguchi, M. Kitamikado, and R. Ueno: Oligosaccharidase activity of a neutral $\beta-N$-acetylglucasaminidase from carp blood. Nippon Suisan Gakkaishi, 57, 325-328 (1991).

7) R. Ueno, X. Yu, and C. Yuan: Purification and characterization of two acidec $\beta$ - $N$-acetylglucosaminidase isozymes from carp blood. Nippon Suisan Gakkaishi, 55, 1407-1413 (1990).

8) R. Ueno, C. Yuan, and Y. Horiguchi: Study of the distribution of $\beta-N$-acetylglucosaminidase in fish blood. Nippon Suisan Gakkaishi, 54, 95-101 (1988).

9) C. Yuan, K. Yoshioka, R. Ueno, and M. Kitamikado: Defferentiation of frozen-thawed fish from fresh fish by determination of neutral $\beta$-N-acetylglucosaminidase in the blood. Nippon Suisan Gakkaishi, 54, 2143-2148 (1988).

10) M. Kitamikado, C. Yuan, K. Yoshioka, and R. Ueno: A routine method and test paper for differentiation between frozen-thawed and fresh fish. Nippon Suisan Gakkaishi, 54, 2149-2151 (1988). 